\title{
Penetrerende hodetraume
}

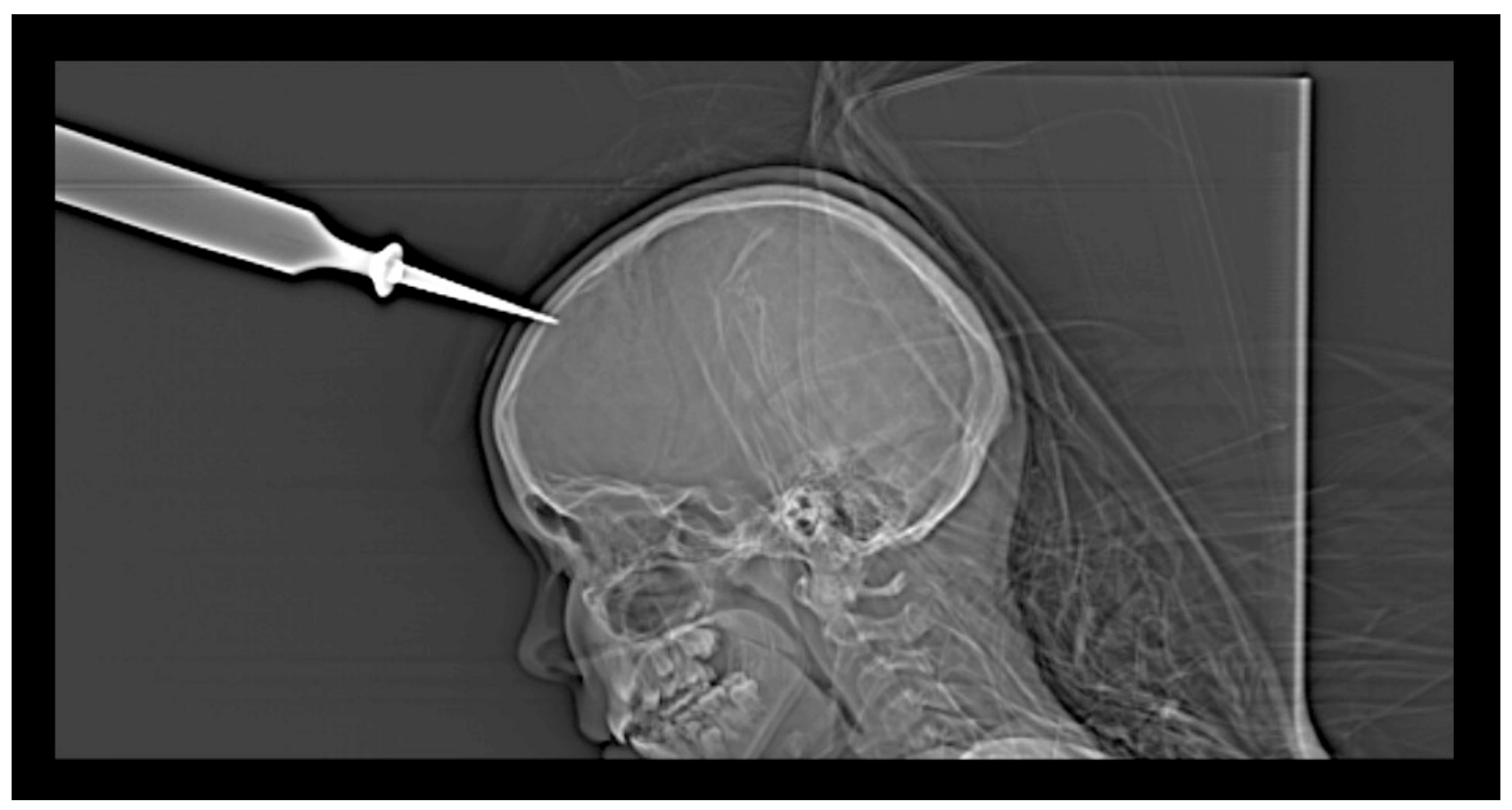

En jente i skolealder ble brakt til sykehus etter en ulykke der hun utilsiktet var blitt truffet av et tappjern, som ble sittende fast $\mathrm{i}$ pannen. Jenta var hele tiden ved bevissthet, og fremmedlegemet ble aldri fors $ø$ kt fjernet før innleggelsen.

Da pasienten ankom sykehuset, var hun våken (Glasgow Coma Scale skår 15), og det var ingen påvisbare nevrologiske utfall. Det ble tatt CT caput (scout-bilde) i akuttmottaket. CT-undersøkelsen viste at tappjernet penetrerte kraniet (bilde), men det var ingen tegn til skade på parenkym eller noen intrakranial blødning. Tappjernet sto nær midtlinjen, og man fryktet skade av fremre del av sinus sagittalis superior, med potensiell blødningsrisiko. Pasienten ble tatt direkte til operasjonsstuen og lagt i narkose, og tappjernet ble fjernet. Spissen penetrerte så vidt dura, uten at det forelå skade på sinus sagittalis superior. Duradefekten ble reparert med et durasubstitutt (Duragen), og det ble gjort en kirurgisk revisjon av sårkanalen. Pasienten fikk tetanusprofylakse og antibiotikaprofylakse preoperativt. Postoperativt fikk hun antibiotika intravenøst i en uke. Det oppsto ingen komplikasjoner etter hodetraumet.
Penetrerende hodetraumer hos barn er på verdensbasis dominert av skudd- og stikkskader (1), men ses sjelden i Norge. Ved mistanke om penetrerende hodeskade bør pasienten etter vår vurdering innlegges i sykehus og undersøkes med CT caput. Dette er viktig for raskt å kunne avdekke behovet for kirurgisk behandling og for preoperativ planlegging.

Pasient og pårørende har gitt samtykke til at artikkelen blir publisert.

Vi takker Klinikk for bildediagnostikk, St. Olavs hospital, som utførte CT-undersøkelsen.

\section{Johanne Marie Iversen}

johanniv@stud.ntnu.no

Norges teknisk-naturvitenskapelige universitet

\section{Sasha Gulati}

\section{Kent Gøran Moen}

Nevrokirurgisk avdeling

St. Olavs hospital

og

Institutt for nevromedisin

Norges teknisk-naturvitenskapelige universitet
Johanne Marie Iversen (f. 1989) er medisinog forskerlinjestudent.

Forfatter har fylt ut ICMJE-skjemaet og oppgir ingen interessekonflikter.

Sasha Gulati (f. 1981) er ph.d., spesialist i nevrokirurgi og overlege.

Forfatter har fylt ut ICMJE-skjemaet og oppgir ingen interessekonflikter.

Kent Gøran Moen (f.1982) er lege i spesialisering i nevrokirurgi og ph.d.-kandidat.

Forfatter har fylt ut ICMJE-skjemaet og oppgir ingen interessekonflikter.

\section{Litteratur}

1. Schecter SC, Betts J, Schecter WP et al. Pediatric penetrating trauma: the epidemic continues. J Trauma Acute Care Surg 2012; 73: $721-5$.

Mottatt 1.2. 2013, første revisjon innsendt 11.3. 2013, godkjent 16.4. 2013. Medisinsk redaktør Merete Kile Holtermann. 